\title{
A SIMPLE SPECTROPHOTOMETRIC DETERMINATION OF TRACE AMOUNTS OF VANADIUM USING THIONIN
}

\author{
Tom Cherian and B. Narayana* \\ Department of Post Graduate Studies and Research in Chemistry, \\ Mangalore University, Mangalagangothri - 574 199, Karnataka, India
}

(Received November 28, 2004; revised December 31, 2004)

\begin{abstract}
A simple and sensitive spectrophotometric method has been developed for the determination of trace amounts of vanadium using thionin as a chromogenic reagent. The proposed method is based on the reaction of vanadium $(\mathrm{V})$ with potassium iodide in acid medium to liberate iodine, which bleaches the violet colour of thionin and is measured at $600 \mathrm{~nm}$. This decrease in absorbance is directly proportional to the vanadium(V) concentration and obeys Beer's law in the range of $0.2-10 \cdot \mathrm{gmL}^{-1}$ of $\mathrm{V}(\mathrm{V})$. The molar absorptivity, Sandell's sensitivity, detection limit and quantitation limit of the method were found to be $2.298 \times 10^{4} \mathrm{Lmol}^{-1} \mathrm{~cm}^{-1}, 0.52 \times 10^{-2} \cdot \mathrm{gcm}^{-}$ ${ }^{2}, 0.035 \bullet \mathrm{gmL}^{-1}$ and $0.11 \bullet \mathrm{gmL}^{-1}$, respectively. The optimum reaction conditions and other analytical conditions were evaluated. The effect of interfering ions on the determination is described. The developed method has been successfully applied to the analysis of the vanadium in synthetic and alloy samples.
\end{abstract}

KEY WORDS: Vanadium determination, Spectrophotometry, Thionin

\section{INTRODUCTION}

Vanadium poisoning is an industrial hazard [1]. Environmental scientists have declared vanadium as a potentially dangerous chemical pollutant that can play havoc with the productivity of plants, crops and the entire agricultural system. High amounts of vanadium are said to be present in fossil fuels such as crude petroleum, fuel oils, some coals and lignite. Burning of these fuels releases vanadium into the air that then settles on the soil. There are cases of vanadium poisoning, the symptoms of which are nervous depression, coughing, vomiting, diarrhoea, anaemia and increased risk of lung cancer, that are some times fatal [2]. Recently, vanadium has been noticed as the index element in urban environmental pollution, especially air pollution [3]. Laboratory and epidemiological evidences suggest that vanadium may also play a beneficial role in the prevention of heart disease [4]. Shamberger [5] has pointed out that human heart disease death rates are lower in countries where more vanadium occurs in the environment.

Many methods have been reported for the determination of vanadium, such as inductively coupled plasma atomic emission spectrometry [6], mass spectrometry [7] and atomic absorption spectrometry [8]. Some of the reported chromogenic reagents for the spectrophotometric determination of vanadium are rhodamine [9], thioproperazine bis(methane sulphonate) [10], indigo carmine [11], 1-naphthyl red [12,13], o-phenylenediamine [14], chromotropic acid [15], 1,8-diaminonaphthalene [16], 2-(5-chloro-2-pyridylazo)-5-dimethylamonophenol [17], 1,5diphenylcarbazide [18], caffeic acid [19]. However, most of these methods suffer from a number of limitations, such as interference by a large number of ions [9-11], low sensitivity [9, $10,14]$ and need extraction in to organic solvents $[17,19]$. Therefore a sensitive, simple and reliable method for the determination of vanadium is clearly recognized.

*Corresponding author. Fax: 0091-824-2287367. E-mail: nbadiadka@yahoo.co.uk 
The present investigation reports a simple, sensitive and selective method for the determination of trace amounts of vanadium using a new reagent thionin. The proposed method is free from interferences of $\mathrm{Ag}^{+}, \mathrm{Al}^{3+}, \mathrm{Mo}^{6+}, \mathrm{Ti}^{4+}, \mathrm{Th}^{4+}$ and $\mathrm{Zr}^{4+}$ hence it is more selective than some of the other methods reported in the literature [9-11]. The proposed method is also more sensitive than some reported methods in the literature $[9,10,14]$ and no extraction is required using organic solvents. The developed method has been successfully applied to the determination of vanadium in synthetic mixtures and alloys.

\section{EXPERIMENTAL}

\section{Apparatus}

A Secomam Anthelie NUA 002 UV-Visible spectrophotometer with $1 \mathrm{~cm}$ quartz cell was used for the absorbance measurements and a WTW $\mathrm{pH} 330 \mathrm{pH}$ meter was used for $\mathrm{pH}$ measurements.

\section{Reagents}

All chemicals used were of analytical grade and distilled water was used for dilution of reagents and samples. Standard stock solution of vanadium(V) $\left(1000 \mu \mathrm{gmL}^{-1}\right)$ was prepared by dissolving $0.2394 \mathrm{~g}$ of $\mathrm{NaVO}_{3}$ in $100 \mathrm{~mL}$ of water and standardized volumetrically [20]. Vanadium alloys (GKW steel, India) and solutions of $2 \mathrm{M} \mathrm{HCl}, 1 \mathrm{M}$ sodium acetate and $2 \% \mathrm{KI}$ were used. A $0.1 \%$ solution of thionin was prepared by dissolving $0.1 \mathrm{~g}$ of thionin in water containing $\mathrm{HCl}(2 \mathrm{M}, 1 \mathrm{~mL})$ and made up to $100 \mathrm{~mL}$ with distilled water.

\section{Procedure}

An aliquot of a sample solution containing $0.2-10 \mathrm{~mL}$ of vanadium solution was transferred into a series of $25 \mathrm{~mL}$ calibrated flasks and $1 \mathrm{~mL}$ of $2 \% \mathrm{KI}$, followed by $1 \mathrm{~mL}$ of $2 \mathrm{M} \mathrm{HCl}$, were added to it. The mixture was gently shaken $(1 \mathrm{~min})$ for the liberation of iodine. Then, $0.5 \mathrm{~mL}$ of $0.1 \%$ thionin was added to it, followed by the addition of $2 \mathrm{~mL}$ of a $1 \mathrm{M}$ sodium acetate solution. The contents were diluted to the mark with distilled water and mixed well. The absorbance of the resulting solution was measured at $600 \mathrm{~nm}$ against the corresponding reagent blank. A blank was prepared by replacing the analyte (vanadium) solution with distilled water. The absorbance corresponding to the bleached colour which in turn corresponds to the analyte (vanadium) concentration was obtained by subtracting the absorbance of the blank solution from that of test solution. The amount of the vanadium present in the volume taken was computed from the calibration graph.

\section{Procedure for the determination of vanadium $(V)$ in alloy and synthetic mixtures}

An accurately weighed amount of vanadium steel (approximately $0.5 \mathrm{~g}$ ) was treated with concentrated $\mathrm{H}_{2} \mathrm{SO}_{4}(15 \mathrm{~mL})$ and concentrated $\mathrm{HNO}_{3}(1 \mathrm{~mL})$ and the solution boiled gently to dissolve the sample. The oxides of nitrogen formed were expelled, the solution cooled and diluted to $25 \mathrm{~mL}$ with doubly distilled water, and treated with $10 \mathrm{~mL}$ of $2 \mathrm{M} \mathrm{HCl}$ and $10 \mathrm{~mL}$ of methyl isobutyl ketone to extract iron [21, 22]. Aqueous layer was separated and potassium permanganate solution $(0.01 \mathrm{~N})$ was added dropwise until the solution appeared pink. The solution was allowed to stand to $5 \mathrm{~min}$, warmed and oxalic acid solution $(0.05 \mathrm{~N})$ added slowly with stirring until the pink colour of the solution was discharged. The solution was diluted to $100 \mathrm{~mL}$ with distilled water. Using the suitable aliquot of the solution vanadium content was determined using the procedure described above. 
Synthetic mixtures were prepared by mixing exact concentration of different metal ions keeping the composition of the synthetic mixture as constant and $1 \mathrm{~mL}$ of this sample solution was used for the determination of vanadium(V) according to the procedure described above.

\section{RESULTS AND DISCUSSION}

This method involves the liberation of iodine by the reaction of vanadium with potassium iodide in an acidic medium. The liberated iodine selectively bleaches the violet colour of thionin and measured at $600 \mathrm{~nm}$. This decrease in absorbance is directly proportional to the vanadium $(\mathrm{V})$ concentration and obeys Beer's law in the range of $0.2-10 \mu \mathrm{gmL}^{-1}$ of $\mathrm{V}(\mathrm{V})$. The coloured species of thionin showed its maximum absorption at $600 \mathrm{~nm}$. The reaction system is represented in Scheme 1 .

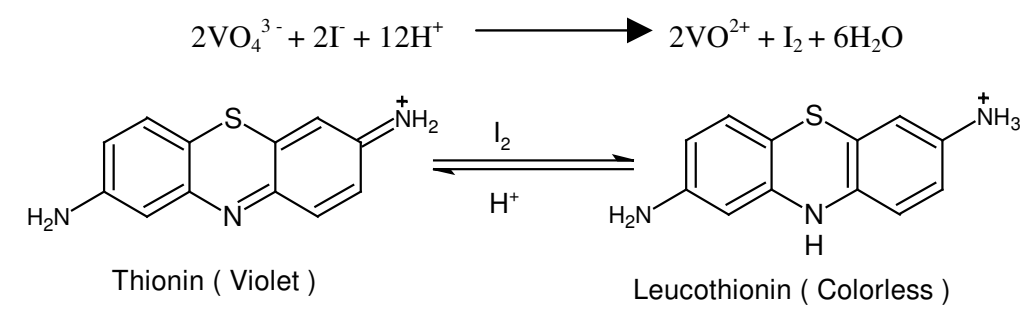

Scheme 1

Effect of the iodide concentration and acidity

The effect of iodide concentration and acidity on the decolourization was studied with $2 \mu \mathrm{gmL}^{-1}$ vanadium solution. The oxidation of iodide to iodine by vanadium was effective in the $\mathrm{pH}$ range $1.0-1.5$, which could be maintained by adding $1 \mathrm{~mL}$ of $2 \mathrm{M} \mathrm{HCl}$ in a final volume of $10 \mathrm{~mL}$. The liberation of iodine from potassium iodide in an acidic medium was quantitative. It was found that $1-1.2 \mathrm{~mL}$ of $2 \% \mathrm{KI}$ and $1 \mathrm{~mL}$ of $\mathrm{HCl}$ were sufficient for the liberation of iodine from iodide by vanadium and $0.5 \mathrm{~mL}$ of $0.1 \%$ thionin was used for subsequent decolourization. Effect of concentration of iodide in reaction system is presented in Figure 1.

Constant and maximum absorbance value was obtained at $\mathrm{pH}=4 \pm 0.2$. Hence the $\mathrm{pH}$ of the reaction system was maintained at $4 \pm 0.2$ throughout the study. This could be achieved by the addition of $2 \mathrm{~mL}$ of a $1 \mathrm{M}$ sodium acetate solution in a total volume of $25 \mathrm{~mL}$. Effect of $\mathrm{pH}$ on the colour stability is presented in Figure 2. The maximum absorbance was obtained instantaneously and required no heating under the reaction conditions. Under the optimum reaction conditions, the bleached colour system was stable for a period of more than $12 \mathrm{~h}$.

\section{Analytical data}

The adherence to Beer's law was studied by measuring the absorbance values of solutions varying vanadium concentration. A straight line graph was obtained by plotting absorbance against concentration of vanadium. Beer's law obeyed in the range of $0.2-10 \mu \mathrm{gmL}^{-1}$ of vanadium. The molar absorptivity and Sandell's sensitivity [23] for coloured system was found to be $2.298 \times 10^{4} \mathrm{Lmol}^{-1} \mathrm{~cm}^{-1}, 0.52 \times 10^{-2} \mu \mathrm{gcm}^{-2}$, respectively. The detection limit $\left(\mathrm{D}_{\mathrm{L}}=3.3 \sigma / \mathrm{s}\right)$ [24] and quantitaion limit $\left(\mathrm{Q}_{\mathrm{L}}=10 \sigma / \mathrm{s}\right)$ [24] where $\sigma$ is the standard deviation of the reagent blank $(\mathrm{n}=5)$ and $\mathrm{s}$ is the slope of the calibration curve for vanadium determination were found to be $0.035 \mu \mathrm{gmL}^{-1}$ and $0.11 \mu \mathrm{gmL}^{-1}$, respectively.

Bull. Chem. Soc. Ethiop. 2005, 19(2) 


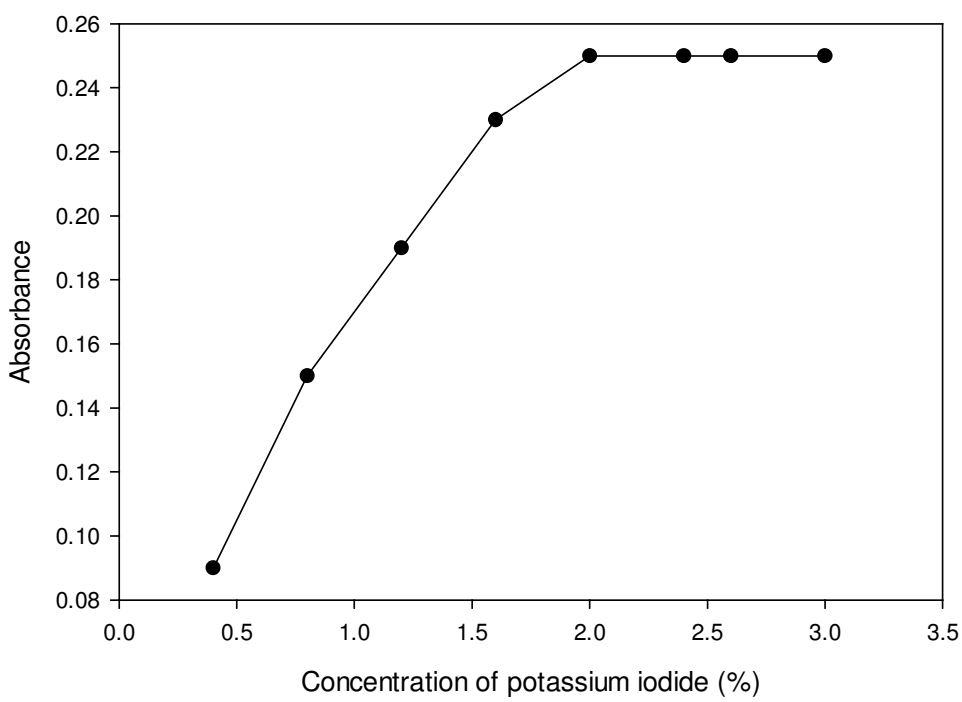

Figure 1. Effect of concentration of potassium iodide (other reagent concentration: $\mathrm{c}\left(\mathrm{V}^{\mathrm{V}}\right)=2$ $\mu \mathrm{gmL}^{-1}, \mathrm{c}(\mathrm{HCl})=2 \mathrm{M}, \mathrm{c}($ thionin $)=0.1 \%$, acetate buffer $\left.\mathrm{pH}=4 \pm 0.2\right)$.

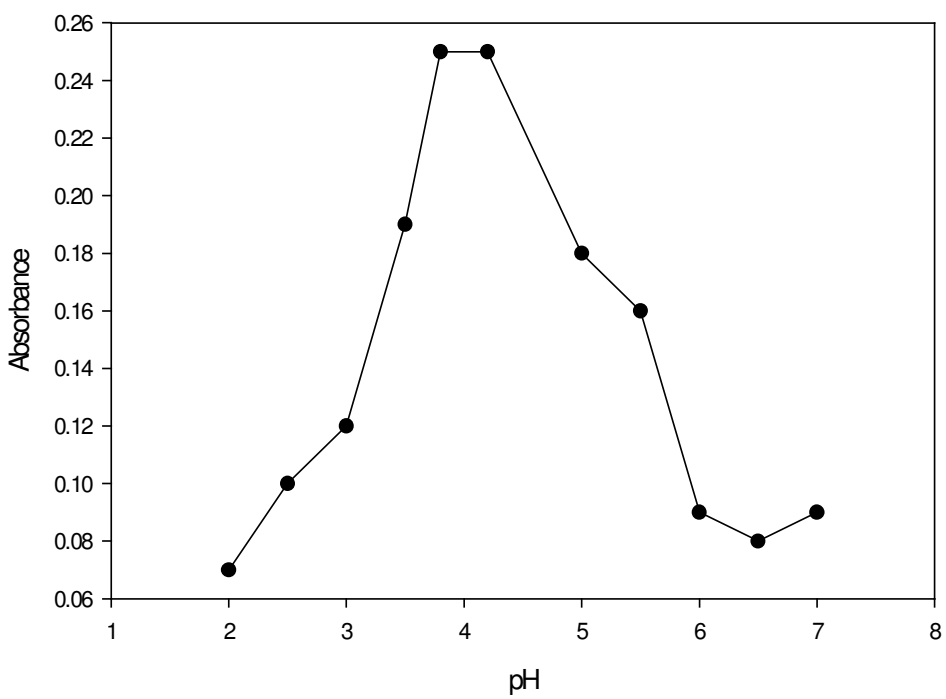

Figure 2. Effect of $\mathrm{pH}$ on colour intensity (other reagent concentration: $\mathrm{c}\left(\mathrm{V}^{\mathrm{V}}\right)=2 \mu \mathrm{gmL}^{-1}$, $\mathrm{c}(\mathrm{HCl})=2 \mathrm{M}, \mathrm{c}(\mathrm{KI})=2 \%, \mathrm{c}($ thionin $)=0.1 \%)$. 
Effect of diverse ions

The effect of various ions at $\mu \mathrm{gmL}^{-1}$ levels on the determination of vanadium was examined. The tolerance limits of the interfering species were established at those concentrations which caused no more than $\pm 2.0 \%$ changes in the absorbance value during the determination of a fixed amount of vanadium $\left(2 \mu \mathrm{gmL}^{-1}\right)$. The tolerance limits of the foreign ions are given in Table 1. In this reaction system, various oxidants such as $\mathrm{CrO}_{4}{ }^{2-}, \mathrm{Fe}^{3+}$ and $\mathrm{Ce}^{4+}$ interfere. $\mathrm{Fe}^{3+}$ can be extracted by using methyl isobutyl ketone [21, 22].

Table 1. Effect of diverse ions on the determinations of $2 \mu \mathrm{gmL}^{-1}$ vanadium(V).

\begin{tabular}{|l|l|l|l|}
\hline Foreign ions & $\begin{array}{l}\text { Tolerance limit } \\
\left(\mu \mathrm{gmL}^{-1}\right)\end{array}$ & Foreign ions & $\begin{array}{c}\text { Tolerance limit } \\
\left(\mu \mathrm{gmL}^{-1}\right)\end{array}$ \\
\hline $\mathrm{Fe}^{3+}$ & 10 & $\mathrm{Ti}^{4+}$ & 1500 \\
$\mathrm{Ni}^{2+}$ & 250 & $\mathrm{Mo}^{6+}$ & 250 \\
$\mathrm{Cu}^{2+}$ & 5 & $\mathrm{Ce}^{4+}$ & 5 \\
$\mathrm{Cd}^{2+}$ & 500 & $\mathrm{~F}$ & 100 \\
$\mathrm{Hg}^{2+}$ & 750 & $\mathrm{CO}_{3}{ }^{2-}$ & 2000 \\
$\mathrm{Ba}^{2+}$ & 1000 & $\mathrm{PO}_{4}^{3-}$ & 1500 \\
$\mathrm{Bi}^{3+}$ & 500 & Citrate & 1000 \\
$\mathrm{Mn}^{2+}$ & 750 & Tartarate & 1500 \\
$\mathrm{Al}^{3+}$ & 500 & Oxalate & 1500 \\
$\mathrm{Ca}^{2+}$ & 1500 & Sulfate & 1000 \\
$\mathrm{Co}^{2+}$ & 1000 & Chloride & 1000 \\
$\mathrm{In}^{3+}$ & 2000 & Acetate & 1000 \\
$\mathrm{Gd}^{3+}$ & 500 & & \\
\hline
\end{tabular}

\section{Application}

The developed method was applied to the quantitative determination of vanadium in alloy and synthetic samples, the results are presented in Table 2 and 3, respectively. The effect of interference of $\mathrm{Fe}^{3+}$ was removed by extracting it with methyl isobutyl ketone. The precision of the proposed method was evaluated by replicate analysis of samples containing vanadium at three different concentrations.

Table 2. Determination of vanadium in vanadium steels (GKW steel, India).

\begin{tabular}{|c|c|c|c|c|c|}
\hline Sample & Composition (\%) & $\% \mathrm{~V}$ present & $\% \mathrm{~V}$ found $^{\mathrm{a}}$ & $\begin{array}{l}\text { Relative } \\
\text { error }(\%)\end{array}$ & $\mathrm{b}_{\text {t-test }}$ \\
\hline 1032 & $\begin{array}{l}\text { C, 0.56; Si, 0.24; Mn, 0.91; Ni, 0.23; } \\
\text { Cr, 1.03; Mo, 0.04; V, 0.12; Cu, 0.19; } \\
\text { P, 0.022; S, 0.018 }\end{array}$ & 0.120 & $0.119 \pm 0.08$ & -0.83 & 2.04 \\
\hline 10820 & $\begin{array}{l}\text { C, } 0.17 ; \mathrm{Si}, 0.13 ; \mathrm{Mn}, 0.53 ; \mathrm{Ni}, 0.20 \\
\mathrm{Cr}, 0.20 ; \mathrm{Mo}, 0.85 ; \mathrm{V}, 0.28 ; \mathrm{Cu} \\
0.10 ; \mathrm{P}, 0.015 ; \mathrm{S}, 0.025\end{array}$ & 0.280 & $0.283 \pm 0.01$ & +1.07 & 0.67 \\
\hline 7110 & $\begin{array}{l}\text { C, } 0.18 ; \mathrm{Si}, 0.34 ; \mathrm{Mn}, 0.33 ; \mathrm{Ni}, 0.12 \\
\mathrm{Cr}, 1.08 ; \mathrm{Mo}, 0.85 ; \mathrm{V}, 0.87 ; \mathrm{Cu}, 0.22 \\
\mathrm{P}, 0.018 ; \mathrm{S}, 0.012 ; \mathrm{Ti}, 0.11 ; \mathrm{Al}, 0.042 \\
\mathrm{~B}, 0.0009\end{array}$ & 0.870 & $0.879 \pm 0.02$ & +1.03 & 1.01 \\
\hline
\end{tabular}

a. Mean \pm standard deviation $(n=5)$. b. Tabulated t-value for 4 degrees of freedom at $\mathrm{P}(0.95)$ is 2.78 . 
Table 3. Determination of vanadium in some synthetic mixtures.

\begin{tabular}{|l|l|c|c|c|}
\hline Sample & Compositions of mixture $\left(\mu \mathrm{gmL}^{-1}\right)$ & \multicolumn{2}{|c|}{ Vanadium(V) } & \multirow{2}{*}{$\begin{array}{c}\text { Recovery } \\
(\%)\end{array}$} \\
\cline { 3 - 4 } & & $\begin{array}{c}\text { Added } \\
\mu \mathrm{gmL}^{-1}\end{array}$ & $\begin{array}{c}\text { Found } \pm \mathrm{SD} \\
\mu \mathrm{gmL}^{-1}\end{array}$ & \\
\hline 1 & $\mathrm{Ni}^{2+}(50), \mathrm{Fe}^{2+}(20), \mathrm{Co}^{2+}(50)$ & 2.0 & $1.99 \pm 0.03$ & 99.5 \\
& & 4.0 & $3.97 \pm 0.05$ & 99.3 \\
\hline 2 & $\mathrm{Al}^{3+}(60), \mathrm{Ce}^{3+}(50)$ & 2.0 & $2.01 \pm 0.02$ & 100.5 \\
& & 4.0 & $3.98 \pm 0.03$ & 99.5 \\
\hline 3 & $\mathrm{Sb}^{5+}(30), \mathrm{Pd}^{2+}(50), \mathrm{Cd}^{2+}(50)$ & 2.0 & $2.0 \pm 0.04$ & 100.0 \\
& & 4.0 & $3.96 \pm 0.07$ & 99.0 \\
\hline 4 & $\mathrm{Al}^{3+}(40), \mathrm{Zn}^{2+}(7) \mathrm{Cu}^{2+}(2.5)^{*}, \mathrm{Fe}^{2+}(0.35)$ & 2.0 & $1.96 \pm 0.03$ & 98.0 \\
& & 4.0 & $4.01 \pm 0.08$ & 100.3 \\
\hline 5 & $\mathrm{Fe}^{2+}(5), \mathrm{Ni}^{2+}(2.3), \mathrm{Cr}^{3+}(2), \mathrm{Mn}^{2+}(0.1)$ & 2.0 & $1.99 \pm 0.05$ & 99.5 \\
& & 4.0 & $3.97 \pm 0.02$ & 99.3 \\
\hline
\end{tabular}

Sample 4 is analogous to vanadium alloy and sample 5 is analogous to Nichroloy (cast). ${ }^{*} \mathrm{Cu}^{2+}$ is masked by 2-mercaptoethanol.

\section{CONCLUSION}

For the first time, thionin has been used as a chromogenic reagent for the spectrophotometric determination of vanadium. The proposed method is free from interferences of common metal ions such as $\mathrm{Ag}^{+}, \mathrm{Al}^{3+}, \mathrm{Mo}^{6+}, \mathrm{Ti}^{4+}, \mathrm{Th}^{4+}$, and $\mathrm{Zr}^{4+}$ and also more sensitive than some reported methods in the literature $[9,10,14]$. The interference of $\mathrm{Fe}^{3+}$ is removed by extracting with methyl isobutyl ketone. No extraction step is involved in the method proposed. The proposed method can be applied to the determination of vanadium in alloy and synthetic samples.

\section{ACKNOWLEDGEMENT}

Authors thank the Microtron Centre of Mangalore University (India) for the technical help.

\section{REFERENCES}

1. Clayton, G.D.; Clayton, F.E. (Eds.), Patty's Industrial Hygiene and Toxicology, Vol. 2A, 3rd ed., Wiley: New York; 1981; p 2013.

2. Venugopal, B.; Luckey, T.D. Metal Toxicity in Mammals, Vol. 2, Plenum Press: New York; 1979; p 220.

3. Langard, S.; Norseth, T.; Friberg, L.; G.F. Nordberg, G.F.; Vouk, V.B. (Eds.), Handbook on the Toxicology of Metals, Elsevier: Amsterdam; 1986.

4. Mracova, M.; Jirova, D.; Janci, H.; Lener, J. Sci. Total Environ. 1993, 16, 633.

5. Shamberger, R.J.; Gunsch, M.S.; Willis, C.F.; McCormark, I.J.; Hemphill, D.D. (Eds.), Trace Substances in Environmental Health XII, University of Mossouri: Colombia; 1978.

6. Da Silva, W.G.P.; Campos, R.C.; Mickeley,N. Anal. Lett. 1998, 31, 1061.

7. Al-Swaidan, H.M. Anal. Lett. 1993, 26, 141.

8. Adachi, A.; Asai, K.; Koyama, Y.; Matsumoto, Y.; Okano, T. Anal. Lett. 1998, 31, 1769.

9. Liu, X.P.; Zhang, Z.Q.; Lihua Jianyan (Huaxue Fence) 1998, 34, 101.

10. Gowda, H.S.; Rekha, G.K. Ind. J. Chem. 1998, 26A, 984.

Bull. Chem. Soc. Ethiop. 2005, 19(2) 
A simple spectrophotometric determination of trace amounts of vanadium using thionin 161

11. Massoumi, A.; Tavallali, H. Anal. Lett. 1998, 31, 193.

12. Wang, H.S.; Zhang, A.M. Microchem. J. 1997, 57, 218.

13. Zhang, A.M.; Wang, H.S.; Cui, H.; Wang, S.H. Fenxi Huaxue 1997, $25,494$.

14. Kawakubo, S.; Ogihara, K.; Iwatsuki,M. Bunseki Kagaku 1996, 45, 965.

15. Zhu, H.Y.; Yang, X.Y.; Zhang, L. Fenxi Shiyanshi, 1994, 13, 38.

16. Gao, J.; Zhang, X.; Yang, W.; Zhao, B.; Hou, J.; Kang, J. Talanta 2000, 51, 447.

17. Zucchi, C.; Forneris, M.; Martinez, L.; Olsina, R.; Marchevsky, E. Fresenius J. Anal. Chem. 1998, 360, 128.

18. Ahmed, M. J.; Banoo, S. Talanta 1999, 48, 1085.

19. Shah, N.; Desai, M.N. Talanta 1991, 38, 649.

20. Vogel, A.I. A Textbook of Quantitative Inorganic Analysis, 5th ed., Longman: London; 1989; p 404.

21. Kamburova, M. Talanta 1993, 40, 713.

22. Snell, F.D. Photometric and Fluorimetric Method of Analysis, Vol. 1, Wiley: New York; 1978.

23. Sandel, E.B. Colorimetric Determination of Trace of Metals, 3rd ed., Interscience: New York; 1953; p 83.

24. Green, J.M. A Practical Guide to Analytical Method Validation, Anal. Chem.. News and Features, 1996, 305A/309A. 